DEPARTMENT OF THE INTERIOR

U.S. GEOLOGICAL SURVEY

\title{
OBLIQUE MAPS OF ANTARCTICA
}

By Tau Rho Alpha and Arthur B. Ford

MISCELLANEOUS INVESTIGATIONS SERIES

Published by the U.S. Geological Survey, 1989 